\title{
ECONOMIC AND DEMOGRAPHIC DETERMINANTS AND ITS EFFECT ON CONSUMER PURCHASING DECISION IN THE NIGERIAN AUTO- MOBILE INDUSTRY
}

\author{
Henry Diko Koce ${ }^{1}$, Mamman Zacchaeus Ndaba ${ }^{2}$ and Elizabeth Gabriel, Gata ${ }^{3}$ a \\ ${ }^{1}$ Chief Lecturer, Department of Marketing, The Federal Polytechnic, PMB55, Bida, Niger State, Nigeria \\ ${ }^{2}$ Chief Lecturer, Department of Marketing, Polytechnic, Zungeru, Bida Campus, Niger State, Nigeria \\ ${ }^{3}$ Chief Instructor, Department of Business Administration and Management, The Federal Polytechnic, PMB55, Bida, Niger \\ State, Nigeria
}

Received 2 June 2021

Accepted 14 June 2021

Published 30 June 2021

Corresponding Author

Henry Diko Koce, henkoce@yahoo .com

DOI 10.29121/

granthaalayah.v9.i6.2021.3997

Funding: This research received no specific grant from any funding agency in the public, commercial, or not-for-profit sectors.

Copyright: (C) 2021 The Author(s). This is an open access article distributed under the terms of the Creative Commons Attribution License, which permits unrestricted use, distribution, and reproduction in any medium, provided the original author and source are credited.

\section{ABSTRACT}

Consumers are likely influenced by so many factors among them are demographic variables and economic variables, this is important especially in decision of capital expenditure such as the purchase of automobiles. This study investigated the socio demographic determinant of consumer purchase decision in the Nigeria Automobile industry. This study employed the use of survey method as well as descriptive analysis, by which consumers opinion where sampled. The population of the study comprises of car owners residing in Niger state with total car population of 508, 564(NGSDVR, 2012). The sample size of 1110 was determined through Yaro Yamane formula, plus mark up of 30\% margin of non-response which totaled to one thousand four hundred and fortythree respondents. One thousand one hundred questionnaires were filled and returned. To ensure reliability of research instrument a pretest was conducted and the result of Cronch Bach alpha was .887 which is greater than. 70. Regression and correlations analysis was used to analyze the data collected with the aid of the statistical package (SPSS). Hypothesis one result showed a significant relationship between demographic variable and consumer purchase decision of automobile $\left(\mathrm{R}^{2=} .968\right)$ and $\mathrm{P}$ value of.000, finally hypothesis two indicated that economic variables have a great influence on consumer purchase decision of automobiles $\left(\mathrm{R}^{2=} .970\right)$ and $\mathrm{P}$ value of.000. Recommendations was that procedures should take all these variables into consideration in designing products and advertising.

Keywords: Consumers, Demographic Variable, Determinant, Economic Variables 


\section{BACKGROUND OF STUDY}

Nigeria with over one hundred and ninety-five million populations according in 2018 is considered an attractive and large market for automobile products in Africa. There is no doubt that the automobile industry in Nigeria is adding to her economic growth, because the industry integrates with different strata of the economy, and jobs are created. It is evident that as the industry grows and integrates with almost every segment of the economy, the automobile market has a strong and positive multiplier effect and thus propels progress of the nation, (Opara, 2013). Automobile industry in Nigeria has contributed massively to the Nigerian economy, apart from jobs it has created for transporters, it ferries people from one place to another, Agbo (2012), which means that the automobile industry in Nigeria has created time and place utility.

Despite the contributions of automobile industry to Nigerian economy, the sector is characterized with so many problems; Poor leadership in Nigeria for the past two or three decades has negative consequence on the automobile industry. Nigerian economy has been in a poor state for a period of time hence the high tariff imposed on automobiles product that are imported into the country. Bisiriyu (2012). Automobile manufacturers lack funds that they will borrow to expand their businesses as government has not encouraged them in this direction. Clement (2014) say because the government of the country has failed to fund automobile industry in Nigeria, fund scarcity is affecting the industry. Near collapse situation of power sector in Nigeria, has led the Automobile industry to source for alternative power for production, which has affected the price of manufactured products by these companies, (Opara, 2013).

However, in the process of arriving at a decision of buying a particular brand of car by a consumer, he goes through a mental process either consciously or unconsciously, that is referred to as consumer buying decision. Individuals and other factors play a vital role in buying process of an automobile product, they include, the initiator, he is that person who first suggest or think of the idea of buying a particular brand of product, in this circumstance it could be any member of the family i.e., husband, wife or children, role or status in the family, and/or your reference group affect consumer buying decision. The influencer is that person whose views or advice carries some weight in making the final buying decision of a car. While decider, is that person who ultimately makes a buying decision of a car, he makes an actual purchase of brand of car. The person who becomes the final user of the product in this circumstance is referred to as user. Marketers of Automobile products need to study all these actors (initiator, influencer, decider and the user) and focus his marketing programme on them so as to have enough buyers of a company's product, subsequently increasing the profit of the company Armstrong and Kotler (2013).

However, before a consumer will arrive at the actual purchase of a brand of car, the buyer goes through physical and mental process of arriving at a decision of what to buy. Firstly, there is need recognition, for a brand of car to be purchased by an 
individual, some internal and some external factors which may triggered the need for a car. After the need recognition, search for information about car will start in earnest by this prospective customer. The consumer at this level will be forced to search for information about the available brand of cars; he gets such information from personal source, commercial sources and public source. At this level he gets to know about the existence of Toyota, Honda, KIA, and Ford cars. When the consumer is highly involved in the purchase and has the knowledge about significant differences between brands is then called complex buying behavior. In this case the consumer must get relevant information about the product attribute and the marketer must develop brand preference to provide detailed information regarding the product attribute.

The researcher evaluation of alternative and purchase decision of automobile products. Consumers of cars are affected by many factors, but then demographic and economic determinants are the factors researcher relies on to see the extent to which they influence the buying decision.

\section{STATEMENT OF PROBLEM}

These family resources play a major role as it determined consumers purchasing decision power, which is under the control of the nation's economy, that has effect on global economy and, mostly in Nigeria with its numerous challenges in the midst of plenty resources and ardent poverty. Federal offices of statistics in Nigeria (2015) say that "Disposable Personal Income in Nigeria decreased to 14,975,955.26 million NGN in the first quarter of 2014 from 16,922,969.31 million NGN in the fourth quarter of 2013. Disposable Personal Income in Nigeria averaged 8,424,926.12 million NGN from 2007 until 2014, reaching an all-time high of 16,922,969.31 million NGN in the fourth quarter of 2013 and a record low of 117,513.58 million NGN in the first quarter of 2007.

In view of this, the study intends to look at the effect of demographic variables and social variables factors on consumer purchasing decision which plays a major role in the automobile products purchase in Nigeria.

\section{SIGNIFICANCE OF THE STUDY}

The research of this study prescribed the assembler and manufacturer with importance information about the socio-demographic variables in contributing to the purchase buying decision. With globalization, companies compete across borders and cultures. It is important for automobile industry to understand these socio demographic determinants and forecast them before venturing into international market.

The research provided useful tool in developing effective marketing plans. It also provided some insight into Nigeria socio-demographic determinant towards international brand that has influence the consumers purchase decision 
The research may be used as learning material especially within areas related to consumer buying decision. Also, the reports suggested marketing strategies that can boost up purchase of automobile products in Nigeria.

\section{PURPOSE OF THE STUDY}

The guiding aim of this study is to study the Demographic and economic determinants of consumer purchase decision in the Nigerian Automobiles industry, which translate into the following objectives:

1. Explore the role of Demographic variables in purchase decision of automobiles

2. Examine the relationship between Economic variables and consumer automobile Purchase Decision

\section{Research Questions}

The following are the relevant research questions

1. How do demographic variables impacts on buying decision of automobiles?

2. What is the relationship between economic variables and automobile purchase decision?

\section{Research Hypotheses}

$\mathbf{H o}_{1}$ : There is no significant relationship between demographic variables and buying decision of an automobile.

$\mathbf{H o}_{2}$ : There is no significant relationship between economic variables and buying decision of an automobile.

\section{CONCEPTUAL REVIEW}

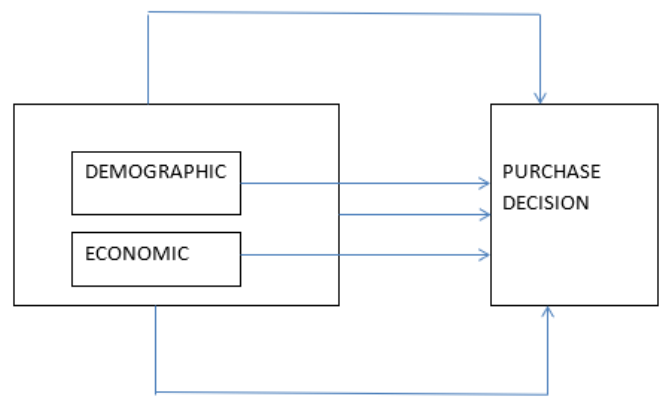

Figure 1 Research Model 


\section{DEMOGRAPHIC VARIABLES}

Demographic characteristics of a potential customer may be defined as the age, gender, race, religion; residence etc. demographic characteristics are important element of every customer in his decision-making process of Automobile products. In purchase decision process of automobile buyers, a demographic characteristic is required and should also be looked into by every car dealer so as to increase sales and benefit of a business. "Demographic characteristics are said to be one of the important elements of purchase decision of Automobile products, satisfaction and also the potential performance depend upon this" A et al. (2012). These demographic characteristics if looked into critically in an Automobile purchase decision can be helpful in not only in understanding the potential customer's behavior but also the problems that may be caused.

D. I. Hawkins et al. (2004) say some personal traits have more importance in purchase decision than identification of others. Age is often a very integral element in homing in on a customer type. In Nigeria automobile like cars are meant for adults to buy, while bicycles are acceptable for children to ride on. Some luxury product sellers like cars target individuals or couples with high disposable income and time to buy for the home Consumers can be classifying into four stages according to age: Children (infant), Teenager, and Middle-aged, Older population. A child will demand to have toys, while teenagers want to keep up with the latest fashion trends.

This variable classifies automobile consumer market into two segments; female and male market. Since the desires, wants, interests and needs of females and males differ, dealers take this into consideration when designing their marketing strategy.

The number of family members or family size is another demographic variable that can be looked into as variable affecting consumer buying decision. This is mainly due to the fact that the number and size of family members directly affects the usage rate of consumer goods. The size of the family also affects consumer buying decision and the size of car purchased D. I. Hawkins et al. (2004).

Nørgaard et al. (2007) believe that race and ethnicity are demographic factors that may or may not come into play in a marketing strategy. In an automobiles industry in Nigeria, it is believed that Northerners (Hausas) prefer Honda products, in the West (Yoruba) they are more to Toyota, while the south especially the Ibos are more at home to Mercedes. If this assumption is proved right, it means that decision to buy a particular brand of Automobile will be affected by buyer's decision process.

Income, education and occupation are closely correlated in that income is often related to a person's education level and job type. Automobile dealers commonly target customers with higher-level incomes and professional backgrounds, because they can afford the products or services. Second hand car dealers or motorcycle dealers tend to focus more on lower -to- middle income earners by emphasizing value, affordability or low-cost cars and services for people on a budget.

Income "is the most important and commonly used factor for assessing an automobile consumer market. The purchasing power of a typical consumer varies based 
on the level of income earned. Based on this demographic variable, consumers are grouped into three categories; high, middle and low income, with the market also classified on the same basis" A et al. (2012). This is due to the fact that high-income consumers tend to give up luxurious goods such as designer clothes.

Abug (2015) required that Demographic Segmentation emphasis on some of these, age and lifestyle, means re-grouping a splitting a market into different age and lifecycle groups. Using sex as a criterion means dividing the market into male and female, with income segmentation is dividing a market based on different income groups.

"Likewise, consumers with middle incomes will put for medium-priced and durable goods, while consumers with low-income purchase and often prefer lower-priced products to satisfy their physical needs. This is because they have less disposable income and hence are sensitive to price changes" Lysander (2011). Manufacturers of home appliances, cars and motorcycles classify their markets based on consumer income.

The occupation of the consumers can greatly influence their buying decisions. This means you must keenly identify professionals that would be interested in your products. In fact, some companies focus on making products that satisfy the needs of certain occupations. Ideally, a senior company executive will buy luxury cars, expensive clothes and subscribe to a golf club membership. Similarly, a teacher will purchase books, papers and pencils as well as lower-priced clothes.

When formulating your marketing blueprint, you can also see an automobile market based on social class, which is divided into three categories: Lower Class, Middle Class, and Upper Class

"The behavior, purchasing power, and motives of consumers vary depending on their social class. As such, upper class consumers tend to buy luxurious products more, while the middle-class consumers tend to buy durable and quality products whilst keeping a close eye on prices and quality. Likewise, consumers in the lower class buy low-priced products that satisfy their physical needs". A et al. (2012).

The stage of the lifecycle may differ among individuals of the same age; some young people may be single, others young and married but with no children, young and married with children, older married persons with dependents, older married persons with no dependents, older divorced persons living alone as well as middleaged married and with dependent children. The list is exhaustive, and is classified based on the products sold. "The differences in life cycle stages influence the objectives of the purchase, desires, buying behaviors and wants." A et al. (2012). Manufacturers of luxury cars such as Ferrari tend to target middle-aged men with no children or young (and wealthy) men with no children.

Religion may not have any serious effect on buying decision of automobile products excepts in other consumables. 


\section{THE ECONOMIC MODEL}

Williams and McCarthy (2012) say that, according to economic model, buyer is a rational man and his buying decisions are fully governed by the concept of utility. If the buyer has purchasing power of choosing a set of services to meet his need. He will allocate this amount over the set of services in a very rational manner with the intention of maximizing the utility or benefits. People are limited by their skills, habits, reflexes, knowledge etc. Buyers operate in an imperfect world in which they do not maximize their decisions in terms of economic considerations such as price-quantity relationships, marginal utility or indifference curve. The buyer usually unwilling to engage in extensive decision-making activities and satisfied with utility or benefits of a product.

\section{EMPIRICAL REVIEW}

John (2013) in his research work "family and its impact on consumer buying behavior of specialty goods "agreed with M and Mehdi (2010) that wives and children always have a high influence on the head of the family (husband in most cases) on purchase decision of specialty goods like cars, electronic, furniture etc. In Polya (2012) Theses of PhD Dissertation "purchase decision making processes and roles within the family" asserts that among each family member undertakes different roles when buying different products. Depending on product type, different family members influence each one who does the actual purchase of a given product. Influencing power of children is determining in the case of products that can be connected to them. Influencing power of children is different on the case of different product.

Mohammed et al. (2010) in their journal article "influence of Brand name on consumer decision making process-An empirical study of car buyers" that when consumer purchase a car, brand names do influence his/her choice. Their study also reveals that branded cars have a great place in consumer mind, when consumers go for purchasing a car; they prefer to purchase a well-known branded car. Customers do not want to try new or unknown branded cars because they have not much information about the lesser-known brand

Ali et al. (2012) in their research work concludes that awareness of quality, awareness of price, innovative characteristics, diversity, loyalty to store and planning influence consumer buying behavior and so these variables have direct and significant relationship with consumer buying behavior

In china, a research was carried out by Quixue and Paul (2010) of Bangkok university of Thailand on the topic "influences on the buying behavior of purchasing commercial housing in Nanning city of Guangxi province, China" it was found out that All the variables used in the research namely culture, Government, marketing activities, reference group, perception, attitudes, learning, motivation, emotion, selfconcept, and lifestyle are simultaneously significant to the dependent variable which is consumer houses-buying behavior 
A research carried out in Kenya, by Stephen, Henry and George (2014) on children's influence on family purchase decision in Kenya, found out that children influence (parent-child relationship and peer group) as moderated by culture, have a positive and significant influence on family purchase decisions in Kenya. In UK, Stone B Z (2012), carried out a research on "the role of peer group and consumer buying decision" that contradict Stephen, Henry and George (2014) of child influence on purchase of cars which say that peer group do not have any significant influence on purchase most cars

\section{RESEARCH METHODOLOGY}

Survey research design was used for this study. For this study, Questionnaire and personal observation was used to collect data from the respondents. Fifteen (15) items questionnaire consist of strictly designed questions to collect data from systematic sampling of 1443 respondents in Niger State.

\section{Validity of the Research Instrument}

Validity is the degree to which instruments measure what it is designed to measure Fowler (2011). The instrument was validated by Academicians, professional buyers, a professor in the field of marketing and sellers in the Nigeria Automobiles industry.

\section{Population and sample size of the study}

The population of study includes number of car owners residing in Niger state. The population of the study is five hundred and sixty-four $(508,564)$ registered car owners. The researcher adopted the Yaros variance formula cited by (Kahne, 2013) that provides a simplified formula to calculate a s ample size. A 95\% confidence level and $\mathrm{e} 0.005$.

$$
\begin{aligned}
& \mathrm{n}=\mathrm{N} \\
& 1+\mathrm{N}(\mathrm{e}) 2
\end{aligned}
$$

\section{Where:}

$\mathrm{n}=$ Sample size

$\mathrm{N}=$ population size

$\mathrm{e}=$ level of precision or significance

$1=$ constant figure

Population of registered car owners in Niger state 508,564

Solving for sample $\mathrm{n}=508,564$

$1+508,564(0.003) 2$

$1+457.7076$

$=558.7076$

$=508,564 / 558.7076$

$=1110.40175$

According to Asika (1999), however there is need for the sample base to be marked up to $30 \%$ margin as non- responses 
Hence, final sample size $=1110(0.3)+400$

$=333+1110$

$=1443$

\section{Method of Data Collection}

Primary source of data was employed by the researcher. Questionnaire were administered in some selected Local Government Area of Niger; One Local Government was selected from each of these three senatorial zones using Quota sampling approach. However, in each of the Zones, three cities were selected where business activities i.e., buying of cars are more in that zone. These cities chosen are the headquarters of senatorial zones. The cities include Minna, Bida and Kontagora. The researcher also employed personal observation to have on-the-spot assessment and better understanding on how consumers engage dealers on purchase of automobile product. The questionnaires were used for this work. The questions were formulated so as to elicit information on the relationship between demographic and economic factors and purchase decision on automobile products. Six Likert-scales type questions, which range from strongly agree to strongly disagree were used (strongly agree $=6$, agree $=5$, fairly agree $=4$, fairly disagree $=3$, disagree $=2$, strongly disagree $=1$ ).

\section{Method of Data Analysis}

In this work, statistical package and service solution (SPSS) 20.0 windows was used for data analysis. Regression analysis was used because it enables the researcher test hypotheses about relationship of two variables; it equally sees whether two variables are associated without necessarily having effect on the relationship.

\section{Data Presentation and analysis}

Table 1 Regression analysis on demographic status effect on automobile purchase

\begin{tabular}{ccccccc}
\hline Model & $\mathbf{R}$ & $\begin{array}{c}\text { R } \\
\text { Square }\end{array}$ & $\begin{array}{c}\text { Adjusted R } \\
\text { Square }\end{array}$ & $\begin{array}{c}\text { Std. Error of the } \\
\text { Estimate }\end{array}$ & $\begin{array}{c}\text { Durbin- } \\
\text { Watson }\end{array}$ & $\begin{array}{c}\text { Sig } \\
\text { Value }\end{array}$ \\
$\begin{array}{c}\text { 1) } \mathrm{Y}=\mathrm{a} \\
\mathrm{b} \text { - } 4 \text { + }\end{array}$ & .984 & .968 & .968 & .868 & 2.102 & .000 \\
\hline
\end{tabular}

Source: research field survey result 2020

The table shows that there is a high correlation of 0.984 , this implies a correlation between the two variables and the effect of demographic factors on buying decision of an automobile is given as .968 coefficients. The adjusted $R$ square shows that even when error has been accounted the effect is still .968 coefficients. The significance value is given as 0.000 which is lower than 0.05 . This means that our estimate is statistically significant them we have to reject the null hypothesis and conclude that there is a significant relationship between demographic variables and consumer buying decision.

The table above gives a summary statistic of the relationship between economic variables and buying decision of an automobile. The correlation value indicates that 
Table 2 Regression analysis of Economic variables effect on automobile purchases

\begin{tabular}{ccccccc}
\hline Model & $\mathbf{R}$ & $\begin{array}{c}\text { R } \\
\text { Square }\end{array}$ & $\begin{array}{c}\text { Adjusted R } \\
\text { Square }\end{array}$ & $\begin{array}{c}\text { Std. Error of the } \\
\text { Estimate }\end{array}$ & $\begin{array}{c}\text { Durbin- } \\
\text { Watson }\end{array}$ & $\begin{array}{c}\text { Sig } \\
\text { Value }\end{array}$ \\
$\begin{array}{c}\text { 1) } \mathrm{Y}=\mathrm{a} \\
=\mathrm{bx} 4+\mathrm{e}\end{array}$ & .985 & .971 & .970 & .836 & 2.102 & .000 \\
\hline
\end{tabular}

Source: research field survey result 2020

there is a high correlation at 0.985 meaning there is high correlation coefficient of .985 between economic variable and buying decision of an automobile. The effect of economic variable on the buying decision of an automobile is shown as 0.971 showing that there is an effect of economic variable on buying decision of automobiles. The adjusted $\mathrm{R}$ square shows the value of the effect when errors and discrepancies have been accounted for. The significance value of the estimate is given as 0.000 indicating statistical significance. As such we will have to reject the null hypothesis and conclude that there is a significant relationship between economic variables and buying decision of an automobile.

\section{DISCUSSION OF FINDINGS}

The study carried out it shows that demographic variables have a significant influence on the consumer buying decision. Therefore, there is a significant relationship between demographic variables and consumer buying decision. In designing automobile product and selling these products, sex and age must be considered.

The study carried out it shows that economic variables have a significant influence on the consumer buying decision of an automobile. Therefore, there is a significant relationship between economic (income) variables and buying decision of an automobile. If an income of an individual improves the more likely of such an individual buying another brand of car becomes higher.

\section{CONCLUSION}

From the study carried out its shows a significant relationship between the demographic variables and economic (income) consumer buying decision in the Nigerian automobile industry

The demographic determinants of consumer buying decision consist of sex, age and income. Realizing the importance of automobile industry in the present economic situation, the researcher has analyzed the effect related to automobile products; hence at this period of our economy, automobile is no more a luxury. The growth in the population of Nigeria and the increasing number of consumers has attracted the attention of automobile manufacturers and marketers. The manufacturers and marketers who study the buying decision of consumers and cater for their needs will be successful. It may be concluded that consumer buying decision has a 
great role to play in automobile industry of economic activities. The research has shown that buyers of automobile products are affected by so many factors; prominent among them are demographic and economic factors.

\section{REFERENCES}

A, S., Suleiman, \& Diko, K. (2012). Marketing Communication In Search Of Professional Excellence Bida.

Abug, J. (2015). Principles And Practice Of Modern Marketing. University Of Nigeria, Department Of Marketing ISBN 978-978. (pp. 49485-49490).

Agbo, C. (2012). A Critical Evaluation Of Motor Vehicle Manufacturing In Nigeria. Nigerian Journal Of Transport, 30, 1-2.

Ali, M., E, N., Ali, \& Maryam, J. (2012). Studying Effects Of Psychological Factors On Consumers Buying Behavior At Iranian Chair Stores. Interdisciplinary Journal Of Contemporary Research In Business, 3(10).

Armstrong, G., \& Kotler, P. (2013). Principles Of Marketing 15th Ed. New York, Irwin McgrawHill.

Armstrong, G., \& Kotler, P. (2014). Marketing: An Introduction. International Journal of Advanced Research In Management And Social Sciences, 3(7).

Asika, N. (1999). Research Methodology In The Behavioural Science. Longman.

Bisiriyu, R. (2012). New Auto Policy Is Ready. Retrieved from Http://Www.Punchng.Com

Clement, U. (2014). Will The New Automotive Policy Give Us Affordable Made-In-Nigeria Car? Vanguard January 13 th.

Fowler, F. J. J. (2011). Survey Research Methods. 3rd Edition,Oaks, CA: Sage Publications..

Hawkins, D. I., Best, R. J., \& Coney, K. A. (2004). Consumer Behaviour: Implications For Marketing Strategy. Business Publications.

Hawkins, I., Best, R. J., \& Coney, K. A. (2011). Consumer Behavior: Building Marketing Strategy. In Irwin/Mcgraw-Hill (Ed.), . New York.

Hossein, N., Kem, O. K., \& Omid. (2013). Do Consumer Based-Factors Influence Consumer Buying Behavior In Automative Industry?(Malaysia Evidence), International Conference On Sociality And Economic Development IPEDR. (Vol. 10).

John, S. (2013). Family And Its Effect On Consumer Buying Behavior Of Specialty Goods., 16, 175-187.

Lysander, N. (2011). Fundmental Of Consumer Behaviour Bida.

M, R. H., \& Mehdi. (2010). The Effect Of Social Factors Affecting Consumer Behavior On Selecting Characteristics Of Purchased Cars. Journal of Business.

Mohammed, A., N, N. T., \& Alexandru. (2010). Influence Of Brand Name On Consumer Decision Making Process-An Empirical Study On Car Buyers. In The Annals Of The 'Stefan Cel Mare' University Of Suceava Fascicle Of The Faculty (Vol. 10).

Nørgaard, M. K., Bruns, K., Christensen, P. H., \& Mikkelsen, M. R. (2007). Children's influence on and participation in the family decision process during food buying. Young Consumers, 8(3), 197-216. 10.1108/17473610710780945

Polya, E. (2012). Management And Business Administration Doctoral School Szent István University Gödöllő. 